\title{
Oxyfluorfen 処理時に抢ける抗酸化能力の植物種間差異
}

\author{
。柳田元継・松本宏・臼茾健二（筑波大・応用生化）
}

ジェニルエーテル系除草剂 oxyfluorfen を柋理された植物はクロロフィル合成系の中間体

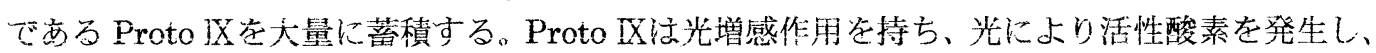
生体膜成分を急速に過酸化すると考えられている。また、生物恬活性酸素による酸化に対する 防御機構を持っていることが知られている。そこで本研究で惊、oxyfluorfen 処理時における Froto XXの蓄積量と脂質過酸化の程度の関係、および、それらと各植物種にお汀る抗酸化能力 との関係について比較・検討を行つた。

\section{【枌料及心゙方法】}

Oxyfluorfenに対して異なる感受性を持つ4種（イネ、トウモロコシ、ダイコン、ソバ）を 用いた。これらを人工気像室内（昼 $25^{\circ} \mathrm{C}(12 \mathrm{~h})$ 、夜 $20^{\circ} \mathrm{C} 、$ 湿度 $60 \% 、 450 \mu \mathrm{E} / \mathrm{m}^{2} \mathrm{~s}$ ) でイネ 科植物は 2 葉期、広葉植物は子葉完全展闗期まで生育させ、以下の実験に供試した。

(1)工タンの放出量 : 植物の茎葉部を暗所で $1 \mu \mathrm{M}$ oxyfluorfen 水溶液に 2 時間浸漬し、苲留水 で楽剂を洗い流した後、ビーカー内に入机密閉した。その後光照射し、ビ一カー内のガスをガ スクロマトグラフで分析した。

(2) Froto IXの定量：上記と同様に薬剂処理した植物の茎葉部から塩基性メ夕ノールで抽出した。 抽出液を遠心して得られた上清を濃縮し、蛍光分光光度棓を備えた HPLCで分析した。

(3)抗酸化系の測定：上記と同様に薬剂処理した植物の茥葉部から粗酵素液を調製した。グル夕 ヂオンリダクターゼ（GR）活性はNADPH の酸化を A 340 の減少で追跡した。スーパーオキシ ドディスムターゼ（SOI)）活性はチトクロームC の還元を $\mathrm{A}_{550}$ の減少で追跡した。還元型・ 酸化型グル夕チオン（GSH・GSSG）は（GR-DTNBリサイクリング法で定量した。カロチノ イドは Lichtenthalerの方法で定量した。

\section{【結果と考察】}

Oxyfluorfen 处理時の活性酸素の発生源と考えられているProto IXの蓄積量はイネ、ソバに おいて大量に、かつ同程度蓄積されるにも関わらず(Fig.1)、過酸化脂質の分解物であるエタン の放出量にはイネ、ソバの間で大きな差暴が認められ、イネでは放出量が小さく、ソバでは大 きかった(Fig.2)。これらの植物種間では Proto IXの蓄積量と脂質過酸化の程度には相関がみら れなかったが、この理由として、Proto IXの光増感反応で発生する活性酸素を消去する抗酸化 能力に差がある可能性が考えられた。各植物種における抗酸化能力を測定したところ、大きな 差異が認められた。抗酸化作用を有するカロチノイド含量には種間で差がみられなかったが (Fig.3)、グルタチオンはダイコンで oxyfluorfen 処理により含量が增大した(Fig.4)。SOD およ び GR はイネで他の種より活性が大きく、かつ oxyfluorfen 処理で活性が増大した。また、ソ バではこれらの活性は検出されなかった(Fig.5, Fig.6)。このことから各植物種が持つ抗酸化能 力は oxyfluorfen に刘する感受性を決定する一要因になりうるものと考えられる。また、イネ において高いレベルを示した SOD はスーパーオキシドを消去する抗酸化酵素であり、また、 還元型 GSH はスーパーオキシド、過酸化水素、過酸化脂質を消去する抗酸化物質として知ら れていることから、膜の過酸化は種々の活性酸素が関与して進むことが推察された。

Yanagida,M., H.Matsumoto and K.Usui : Antioxidative activity in oxyfluorfen-treated plant speicies. 


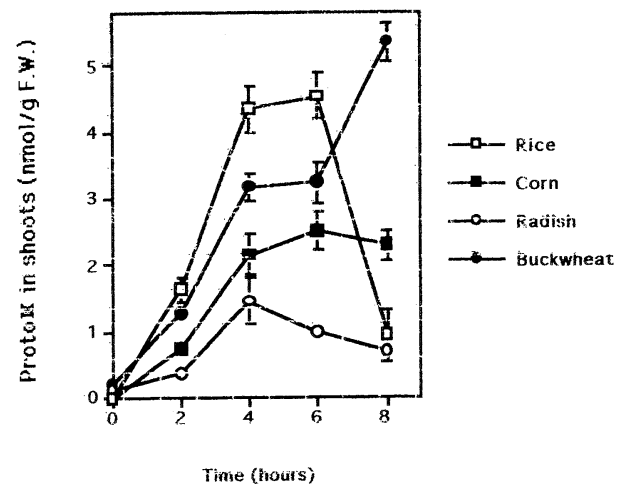

Fig.1

Time course of oxyfluorfen-induced protoporphyriniX accumuiation in the light.
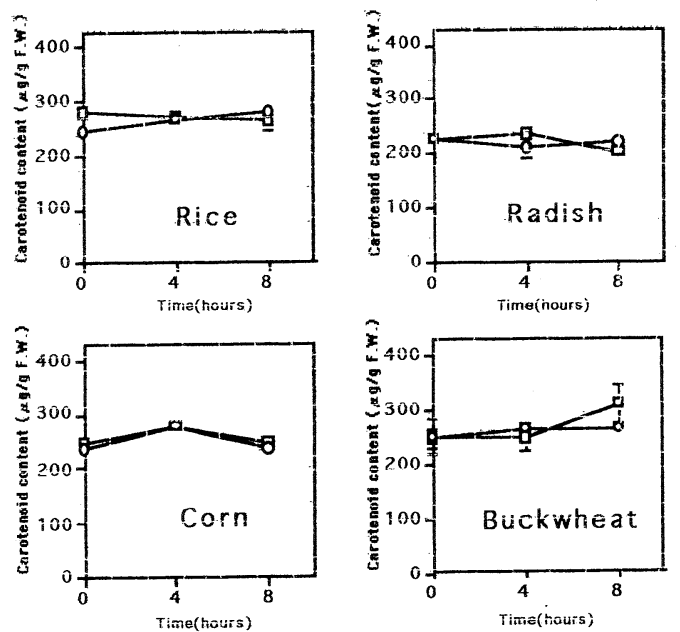

Fig. 3

Effect of oxyfluorfen on carotenoids content: in the light.
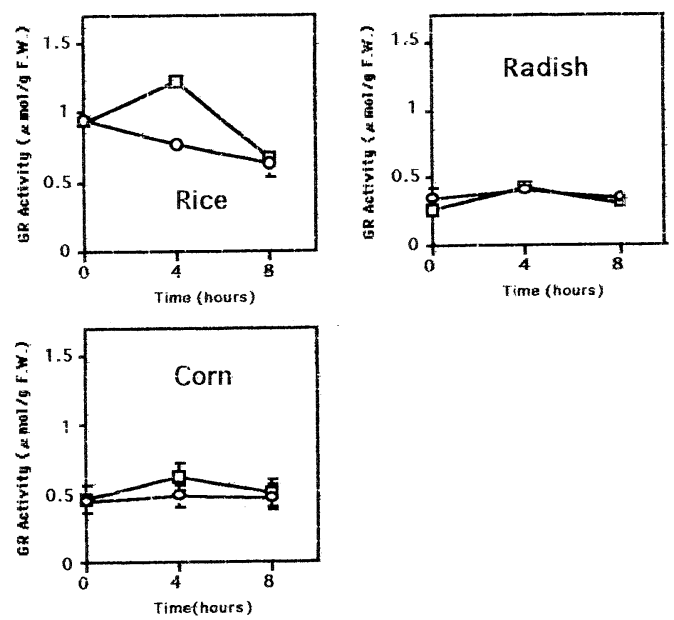

Fig. 5

Effect of oxyfluorfen on glutathione reductase in the light.

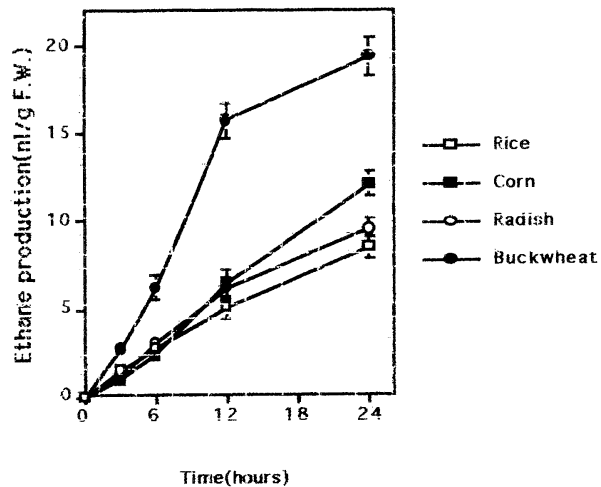

Fig. 2

Time course of oxyfiuorfen-induced ethane production in the light.
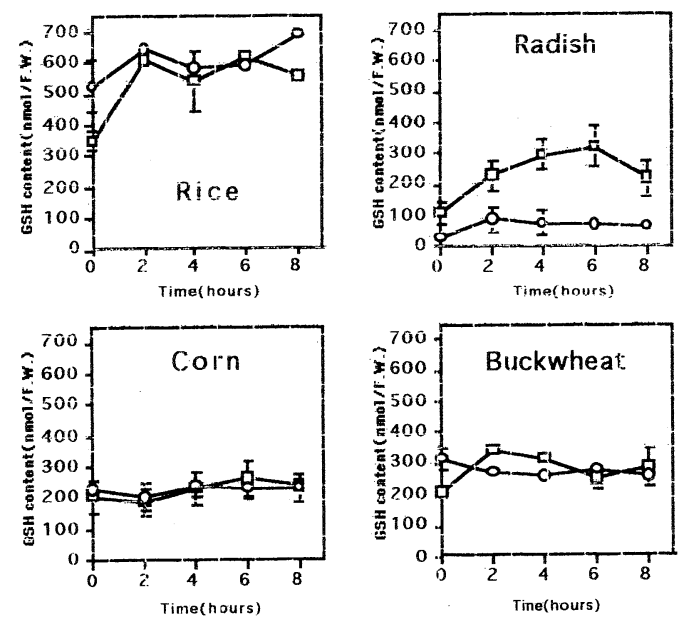

Fig. 4

Effect of oxyfluorfen on GSH conterit in the tight.
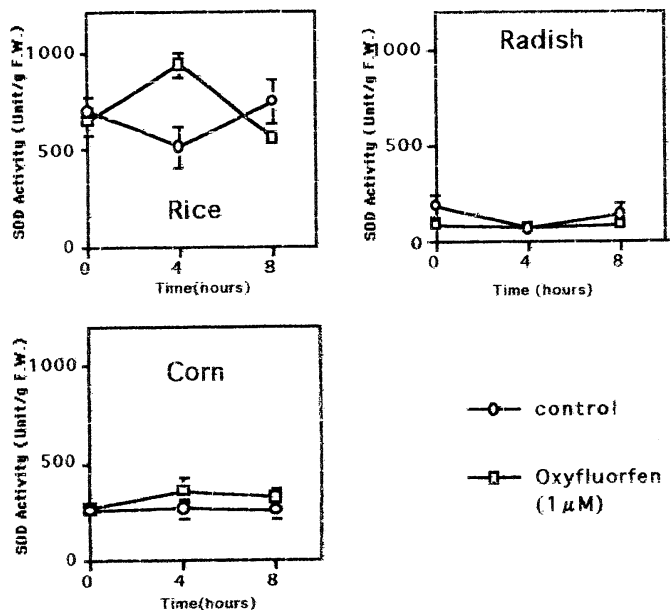

-o- control

$\rightarrow-$ Oxyfluorfen

$(1 \mu \mathrm{M})$

Fig. 6

Effect of oxyfluorfen on superoxide dismutase in the light. 
D C P A ・ N A C 乳剂の非選択性除草剤への混用効果

大谷晴一（八洲化学研究所・小郡分室）

1. 目的

演者らは果樹園・非農耕地等の雑草防除に非選択性除草剂を用いているが、一部の草 種が残草する様になりその対策として、D C P A ・ N A C 乳剤を混用すると残草が少な くなる事を確認したので、今回はこの概要について報告する。

2. 試験方法

試験一 1 : 活性発現の速効性及び倒伏性の増大

試験は S.62 年に当分室のナシ園を 1 区: $3 \mathrm{~m} \times 2 \mathrm{~m}=6 \mathrm{~m}^{2}$ に区画作成し、雑草 の草高：40〜90 c m 時にグリホサート液剂及び D C P A N A C 乳凧を所定量手動 加圧式噴霧器を用いて散布し、4 日後・2 5 日後に観察調査した。表 1

試験 -2 : 効果增強・草種スペクトラムの拡大

試験はH．7 年に当分室のブドウ園を 1 区: $2 \mathrm{~m} \times 2.5 \mathrm{~m}=5 \mathrm{~m}^{2}$ に区画を作成し 雑草の草高：40〜100 c m 時にグルホシネート液放及び D C P A ・ N A C 乳剤を所 定量背負式動力噴霧機を用いて散布し、3 日後・2 5 日後に観察調査した。表 2 試験一 3 : 降雨に対する影響

試験はH，6年に当分室のナシ園を1区：5 $\mathrm{m} \times 4 \mathrm{~m}=20 \mathrm{~m}^{2}$ に区画を作成し、雑 草の草高：40〜80 c m 時にグルホシネート液剤及び D C P A N N C 乳剂を所定量 動力噴霧機を用いて散布し、3 日後・30日後に観察調查した。表 3 - a

また H. 8 年には当分室のキウイフルーツ園を 1 区： $1 \mathrm{~m} \times 0.8 \mathrm{~m}=0.8 \mathrm{~m}^{2}$ の 枠を設け手動加圧式噴霧器を用いて散布し、同様に調査した。表 3 - b

両処理とも降雨が予定される前に行った。(H.6:3 時間後・H.8：2 時間後) 試験 -4 : 処方間の差での活性の比較

試験は S. 63 年に当分室のナシ園の春雑草：草高：20〜40 c m を対象に 1 区:

$2 \mathrm{~m} \times 2 \mathrm{~m}=4 \mathrm{~m}^{2}$ の区画を作成し手動加圧式噴霧器を用いて散布し 14 日後調査した また甘夏ミカンを用い、十分量・直接散布による活性の比較も検討した。表 4

\section{3.試験結果及び考察}

(1):グリホサート単用区では、ヨモギ・トウバナが残草した他、コアカザ・ヒメムカシ ヨモギ・オ二ノゲシ等が立性を維持していたが、D C P A ・ N A C との混用区は、残 草が殆どなく、前記 3 種も倒伏した他、作用発現も混用区の方が、速かった。

(2) : グルホシネート単用区では、ツコクサ・イノコズチ・コヒルガオ及び一部イヌビユ が残存したが、D C P A ・ N A C との混用区はこれらの雑草も殆ど残草せず、効果の 増大・草種スペクトラムの拡大が確認された。

(3) : グルホシネート単用区は少し降雨の影響を受け、オニノゲシ・イヌビュ・エノコロ グサ等が残存したが、D C P A N A C との混用区は残存程度が少なく、作用発現も 速かった。

この事より、D C P A N A C 乳㓮を混用する事により降雨の影響を少なくする事 ができると考えられる。

H. 8 年の試験では、D C P A との混用区も設けたが、この様な作用は認められず D C P A N A C との混用区に認められている。

(4)：試験一 1 と試験 $-2 ・ 3$ に用いたD C P A N A C 乳剤には処方間に差があり、現 処方の方が活性が強く認められた。

この結果より、遅効性ではない非選択性除草剤でも D C P A N A C 乳剂が混用効 果を発揮したものと考えられる。

なお処方間の違いとして乳化粒子が小さく、付着性が旧処方が良くなっている。

S.0tani :Activity of combined application with nonselective herbicides and DCPA -NAC EC. 
表 1.DCPA・NAC乳剂混用によるグリホサート41\%液昘の効果発現及已倒状性の增大試験結果 处理 : $6 / 30$

\begin{tabular}{|c|c|c|c|c|c|c|c|c|c|}
\hline \multirow{2}{*}{ 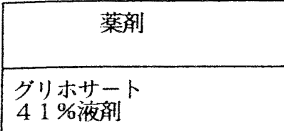 } & \multirow{2}{*}{$\begin{array}{l}\text { 七 } \begin{array}{l}\text { 薬量 } \\
\mathrm{L} / 10 \mathrm{a}\end{array} \\
0.75 \\
0.25\end{array}$} & \multicolumn{6}{|c|}{ 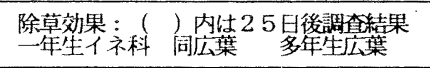 } & \multicolumn{2}{|c|}{ 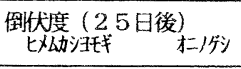 } \\
\hline & & $\begin{array}{l}2 \\
1\end{array}$ & $\left(\begin{array}{l}5 \\
5\end{array}\right)$ & $\begin{array}{l}1.5 \\
0.5\end{array}$ & $\left(\begin{array}{l}5 \\
4\end{array}\right)$ & $\begin{array}{l}1 \\
0.5\end{array}$ & $\left(\begin{array}{l}5) \\
3 \cdot 5)\end{array}\right.$ & $\begin{array}{l}+ \\
\pm\end{array}$ & $+\underset{ \pm}{++}$ \\
\hline $\begin{array}{l}\text { グリホサート+ } \\
\text { DCPA・NAC }\end{array}$ & $\begin{array}{l}0.75+1.5 \\
0.25+1.5\end{array}$ & $\begin{array}{l}3.5 \\
3\end{array}$ & $\left(\begin{array}{l}5 \\
(5)\end{array}\right.$ & & $\begin{array}{l}(5) \\
(5)\end{array}$ & 2.5 & $\left(\begin{array}{l}5 \\
(5)\end{array}\right)$ & $\begin{array}{l}+++ \\
++\end{array}$ & $\begin{array}{l}+++ \\
+++\end{array}$ \\
\hline DCPA-NAC $(25+5) \%$ 乳偊 & 1.5 & 2 & $(4)$ & 1.5 & (3) & 1.5 & $(2.5)$ & $\pm \sim-$ & $\pm \sim-$ \\
\hline 無処理 & & 0 & (4) & 0 & (0) & 0 & $(0)$ & - & - \\
\hline
\end{tabular}

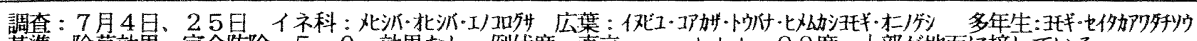

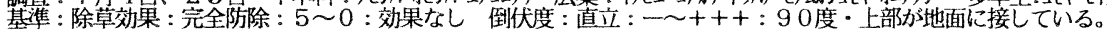

表2. DCPA・NAC乳剂混用によるグルホシネート18。5\%液剂の效果增強及び草㮔の增大試験結果 処理：7／17

\begin{tabular}{|c|c|c|c|c|c|c|c|c|}
\hline 薬剂 & $七 \frac{\text { 薬量 }}{L} / 10 \mathrm{a}$ & 希积倍数 & $\begin{array}{l}\text { 除草 } \\
\text { 一年 }\end{array}$ & 京科）内 & $\begin{array}{l} \pm 25 \text { 日後 } \\
\text { 年生应 }\end{array}$ & 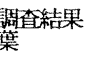 & 多年生広至 & \\
\hline $\begin{array}{l}\text { グルホシネート液阂 } \\
18.5 \%\end{array}$ & 1 3 & $\begin{array}{r}400 \\
1333\end{array}$ & $\begin{array}{l}2.5 \\
1.5\end{array}$ & $\left(\begin{array}{l}5 \\
(4)\end{array}\right.$ & $\begin{array}{l}2 \sim 2.5 \\
1.5 \sim 2\end{array}$ & $\begin{array}{l}(4.5) \\
(3.5)\end{array}$ & $\begin{array}{l}0.5 \sim 1 \\
0.5\end{array}$ & $\left.(4)^{5}\right)$ \\
\hline $\begin{array}{l}\text { グルホシネート+ } \\
\text { DCPA・NAC }\end{array}$ & $\begin{array}{l}1+2 \\
0.3+2\end{array}$ & & $\begin{array}{l}4 \\
3\end{array}$ & $\left(\begin{array}{l}5 \\
5\end{array}\right)$ & $\begin{array}{l}4 \sim 4.5 \\
3.5 \sim 4\end{array}$ & $\left(\begin{array}{l}5) \\
4.5)\end{array}\right.$ & $\begin{array}{l}3.5 \sim 4 \\
3.5\end{array}$ & $\left(\begin{array}{l}5 \\
5\end{array}\right)$ \\
\hline $\mathrm{DCPA} \cdot \mathrm{NAC}$ & 2 & 200 & 1.5 & $(3.5)$ & 2.5 & (3) & 2.5 & (2. 5) \\
\hline 無処理 & & & 0 & (0) & 0 & $(0)$ & 0 & (0) \\
\hline
\end{tabular}

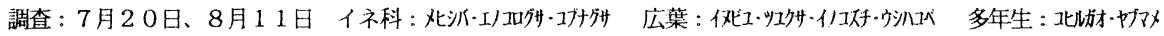

表 3. D C P A ・ NAC乳剤混用に上る降雨の影響に対する効果試験結果

a) H. 6年試験 処理: $7 / 25$ 降雨: $7 / 25$ 夕方〜翌朝: $23 \mathrm{~mm}$

\begin{tabular}{|c|c|c|c|c|c|c|c|c|}
\hline 薬戍 & $七 \frac{\text { 薬量 }}{\mathrm{L} / 10 \mathrm{a}}$ & 希积倍数 & \multicolumn{4}{|c|}{ 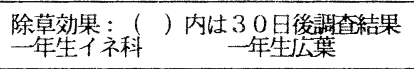 } & \multicolumn{2}{|c|}{ 多年生広葉 } \\
\hline グルホシネート & 0.3 & 333 & $1 \sim 1.5$ & $(4.5)$ & 1.5 & (4) & 1 & (4) \\
\hline $\begin{array}{l}\text { グルホシネート } \\
+\mathrm{DC} \mathrm{PA} \text {-NAC }\end{array}$ & $\begin{array}{l}0.3+3 \\
0.3+1\end{array}$ & & $4.5 \widetilde{r}^{1.5}$ & $\left(\begin{array}{l}5 \\
5\end{array}\right)$ & $\begin{array}{l}4.5 \\
3.5 \sim 4\end{array}$ & $\left\{\begin{array}{l}5 \\
5\end{array}\right)$ & $\begin{array}{l}4 \sim 4.5 \\
3 \sim 3.5\end{array}$ & $\left(\begin{array}{l}5) \\
4 \cdot 5)\end{array}\right.$ \\
\hline $\mathrm{DCPA} \cdot \mathrm{NAC}$ & $\begin{array}{l}3 \\
1\end{array}$ & $\begin{array}{l}100 \\
333\end{array}$ & $\frac{2.5}{2}$ & $\left(\begin{array}{l}4) \\
(3.5)\end{array}\right.$ & $\begin{array}{l}2 \\
1.5\end{array}$ & $\left(\begin{array}{l}4) \\
(3.5)\end{array}\right.$ & 1.5 & $\left(\begin{array}{l}3 \\
3 \\
3\end{array}\right)$ \\
\hline 無処理 & & & 0 & (0) & 0 & (0) & 0 & $(0)$ \\
\hline
\end{tabular}

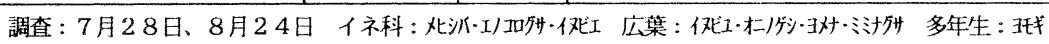

b) H. 8年試験 処理: $9 / 6$ 降雨: $9 / 6$ 夕方〜翌日: $35 \mathrm{~mm}$

\begin{tabular}{|c|c|c|c|c|c|c|c|}
\hline 薬乳 & 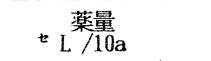 & 除草 & $:(1) 內$ & $\begin{array}{l}+30 \\
1\end{array}$ & $\begin{array}{l}\text { 調相結果 } \\
\text { 手 }\end{array}$ & ユユヒ & \\
\hline グルホシネート & 0.3 & 0.5 & (3) & 1.5 & $(2.5)$ & 2.5 & $(3.5)$ \\
\hline $\begin{array}{l}\text { グルホシネート } \\
+\mathrm{DCPA} \mathrm{PAC}\end{array}$ & $\begin{array}{l}0.3+0.3 \\
0.15+0.15\end{array}$ & $\begin{array}{l}4 \\
3.5\end{array}$ & $\left(\begin{array}{l}5) \\
4,5)\end{array}\right.$ & $\begin{array}{l}4.5 \\
4.5\end{array}$ & $\left(\begin{array}{l}5 \\
5\end{array}\right)$ & 4.5 & $\left(\begin{array}{l}5) \\
4.5)\end{array}\right.$ \\
\hline $\mathrm{DCPA} \cdot \mathrm{NAC}$ & 0.3 & 1 & $(1.5)$ & 1.5 & $(2)$ & 1 & $(1.5)$ \\
\hline 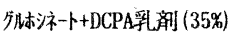 & $0.3+0.21$ & 3.5 & $(3.5)$ & 3 & $(2.5)$ & 3 & (4) \\
\hline 無処理 & & 0 & $(0)$ & 0 & $(0)$ & 0 & (0) \\
\hline
\end{tabular}

調查: 9月9日、10月1日 処理時:ツユクサ：20〜25cm イノコズチ: 40〜60 c m コヒルガオ: $10 \sim 20 \mathrm{~cm}$

表4.DCPA・NAC乳剂の製剂による活性比較試験結果

a) 除草効果の比較

\begin{tabular}{|c|c|c|c|c|}
\hline 薬剤 & $\begin{array}{l}\text { 薬量 } \\
\mathrm{L} / 10 \mathrm{a}\end{array}$ & $\begin{array}{r}\text { 除草効果 } \\
\text { 一年生齐科 }\end{array}$ & 同広葉 & 多年生広葉 \\
\hline $\begin{array}{l}\text { DCPA - NAC乳剂 } \\
\text { 新処方: N0.DD-6-11R }\end{array}$ & $\begin{array}{l}3 \\
1.5\end{array}$ & $\begin{array}{l}4.5 \sim 5 \\
4.5\end{array}$ & $\begin{array}{l}4.5 \\
4\end{array}$ & $\begin{array}{l}4.5 \\
4.5\end{array}$ \\
\hline 冏上 & $\begin{array}{l}3 \\
1.5\end{array}$ & $\begin{array}{l}4.5 \\
3.5 \sim 4\end{array}$ & $\begin{array}{l}4 \sim 4.5 \\
3.5\end{array}$ & 4.5 \\
\hline 無処理 & & 0 & 0 & 0 \\
\hline
\end{tabular}

処理: 5月13日

侪科: メ決公広葉: ヨメナ

多年生:アザミ・ヒメスイバ・アメリカフウロソウ

調查：5月27日 b ）活性の比較 : 甘夏ミカン

\begin{tabular}{|c|c|c|c|}
\hline 薬剂 & 希积倍数 & 彩甜性 & 成葉 \\
\hline $\begin{array}{l}\text { DCPA-NAC } \\
\text { 新処方 }\end{array}$ & $\begin{array}{l}66.7 \text { 倍 } \\
133 \text { ” }\end{array}$ & $\begin{array}{l}+ \\
\pm \sim-\end{array}$ & $=$ \\
\hline 周上 & $\begin{array}{l}66.7 \mathrm{~J} \\
133 \mathrm{~J}\end{array}$ & \pm & $\overline{-}$ \\
\hline 無処理 & & - & - \\
\hline
\end{tabular}

处理: 8月 8日

8 亭鋪植: 3年生・3鉢/区

屋外条件

调查: 8月18日

基濩: 大: $+++\sim$ : 無 


\section{昆虫摂食阻害活性を有する野生植物の検索}

森本 正則、○夈田 澄子、駒井 功一郎（近畿大・農）

【目的】近年、合成農薬の集約的な使用により、種々の問題が生じ、農薬の開発手段 としての天然物の可能性が見直されてきている。天然由来の生理活性物質の探求は、 新規生物活性、新しい作用様式、または化学合成の為のリード化合物発見の可能性を 大いに有していると考えられ、“合成だけ”のアプローチに頼る欠点を補うものとし て期待されている。本研究では、農産物の品質低下の多くは病害虫によって引き起こ されるという事実から、昆虫生理活性物質に着目した。昆虫摂食阻害物質 ( antifeedant) もそのひとつであり、これを害虫管理に取り入れ、害虫の摃食を制 御することによって作物の品質を保ち、加えて害虫の繁殖を制御し、作物保護を達成 する新しい防除剂として将来利用可能なリード化合物の探索を目的とした。本研究で は、昆虫拱食阻害物質を身近に存在する野生植物に注目して検索を行った。

【材料および方法】供試植物は1996 年 3 月から 1997 年 2 月にかけて奈良県および 京都府において食害の少ない健全な植物体を採集した。各供試植物はへキサン、エー テル、メタノールで順次抽出し、減圧濃縮することによりバイオアッセイに用いる試 料とした。活性評価は、リーフディスク法を用い、供試昆虫として蔬菜害虫であるハ スモンヨトウ（Spodoptera litura F.) 幼虫に対する摂食阻害活性効果を指標とした。 直径約 $20 \mathrm{~mm}$ のサツマイモ（Ipomoea batata）の葉を用い、処理区は溶媒で溶解さ せた規定量のサンプル溶液をリーフディスクに均一に塗布した。なお、無処理区は用 いた溶媒のみを処理した。室温で溶媒を完全に除き、湿らせた濾紙上に処理したリ一 フディスクを対角線上に十字に配置した。その後、ハスモンヨトウ 3 令幼虫を 15 匹 放ち、自由に摂食させ、2 ${ }^{\circ} \mathrm{C}$ 、明条件で 2 時間静置した。食害されたリーフディス クは白黒のデータに変換し、スキャナーでコンピュータ処理のためデジタルデータに 変換した。フリーソフトの NIH Image を用いてピクセル（ pixel）単位で比較を行 い、処理区と無処理区の食害率から Alkofahi（1989）らによって提案された式よ り摄食阻害指数を算出し、摂食阻害活性を評価した。なお、本試験は 3 往復行った。

【結果および考察】表 1 に示したように、供試昆虫の食草とされるノゲシの各抽出物 の攝食阻害指数は不活性の50 付近を示し、それに対して昆虫生理活性物質の報告が なされているキランソウやセイタカアワダチソウは高い掑食阻害活性を示した。この 結果より、このバイオアッセイ法は適切であることが示唆された。また、この結果か ら注目すべき植物種は、ハハコグサ、オオバノヤエムグラであり、今後の検討が望ま れる。摂食阻害活性と異なる活性を示したのは夕ネッケバナで、昆虫に対する毒性を 確認した。現在その活性画分を検討中である。現在までの結果から各抽出物と摂食阻 害指数との検討を行ったところ、ヘキサン、エーテル抽出物に摂食阻害物質を有する ことが多く、植物生態との検討を行ったところ、一年生植物よりも多年生、越年生植 物に多いと考えられる。このことは、植物の二次代謝成分が活性成分ではないかと推 測される。

Morimoto, M., S. Kumeda and K. Komai : Screening test of wild plants have insect antifeedant against plant feeding insects. 
表 ハスモンヨトウに対する植物抽出物の摂食阻害指数

\begin{tabular}{|c|c|c|c|c|c|c|}
\hline \multirow[t]{2}{*}{ plant name } & \multicolumn{2}{|c|}{ hexane ext. } & \multicolumn{2}{|c|}{ ether ext. } & \multicolumn{2}{|c|}{ methanol ext. } \\
\hline & index av. & (S.E.) & index av. & (S.E.) & index av. & (S.E.) \\
\hline キランソウ* & 12.96 & $(4.94)$ & 11.41 & $(---)$ & 55.70 & $(22.09)$ \\
\hline ル゙ル & 21.48 & $(3.32)$ & 14.71 & $(6.39)$ & 52.49 & $(7.16)$ \\
\hline スズメノテッポウ & 26.18 & $(11.05)$ & 22.64 & $(6.11)$ & 46.84 & $(9.74)$ \\
\hline$\exists モ キ ゙$ & 33.60 & $(5.30)$ & 4.95 & $(3.37)$ & 41.62 & $(4.73)$ \\
\hline ゲンゲ & 28.53 & $(10.27)$ & 33.21 & $(11.06)$ & 57.41 & $(9.87)$ \\
\hline 十ズナ & 9.74 & $(2.38)$ & 29.67 & $(11.16)$ & 41.00 & $(6.16)$ \\
\hline 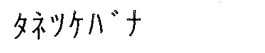 & 25.57 & $(3.50)$ & 8.71 & $(4.32)$ & 38.45 & $(4.56)$ \\
\hline クサノオウ & 14.30 & $(3.81)$ & 19.79 & $(0.51)$ & 34.87 & $(5.82)$ \\
\hline ノアザミ & 17.50 & $(7.61)$ & 8.28 & $(4.72)$ & 31.25 & $(6.22)$ \\
\hline センニンソウ & 20.64 & $(5.45)$ & 35.60 & $(3.73)$ & 56.10 & $(13.51)$ \\
\hline ジンチョウゲ & 47.57 & $(6.39)$ & 17.55 & $(3.67)$ & 23.83 & $(20.14)$ \\
\hline ヒサカキ & 24.66 & $(8.94)$ & 24.34 & $(3.85)$ & 43.32 & $(17.54)$ \\
\hline オオバノヤエムグラ & 12.06 & $(4.74)$ & 27.21 & $(6.21)$ & 53.39 & $(7.29)$ \\
\hline ゲシノショウコ & 60.55 & $(4.01)$ & 23.22 & $(2.30)$ & 51.93 & $(20.89)$ \\
\hline カキドオシ & 18.92 & $(2.02)$ & 11.03 & $(1.38)$ & 41.90 & $(6.56)$ \\
\hline ハハコグサ & 10.26 & $(4.07)$ & 20.88 & $(2.40)$ & 41.55 & $(5.12)$ \\
\hline ヤブカンゾウ & 26.36 & $(4.67)$ & 30.44 & $(15.18)$ & 41.23 & $(14.40)$ \\
\hline 朴ケノザ & 23.69 & $(4.74)$ & 35.73 & $(4.22)$ & 40.78 & $(11.85)$ \\
\hline コオニ处゙ラコ & 19.57 & $(9.52)$ & 13.17 & $(4.91)$ & 48.22 & $(2.87)$ \\
\hline 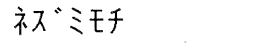 & 25.99 & $(8.02)$ & 21.07 & $(8.53)$ & 49.75 & $(2.07)$ \\
\hline スズメノやリ & 27.72 & $(7.89)$ & 8.12 & $(1.81)$ & 38.49 & $(3.13)$ \\
\hline ヒガンバナ & 16.47 & $(3: 66)$ & 31.10 & $(3.28)$ & 26.47 & $(9.84)$ \\
\hline ウサギアオイ & 31.92 & $(10.08)$ & 16.38 & $(6.95)$ & 43.17 & $(4.88)$ \\
\hline オオバコ & 20.35 & $(11.04)$ & 13.43 & $(8.69)$ & 39.46 & $(10.95)$ \\
\hline ウマノアシガタ & 18.44 & $(10.53)$ & 11.41 & $(1.33)$ & 19.61 & $(11.83)$ \\
\hline ノボロギク & 31.80 & $(3.87)$ & 25.78 & $(6.54)$ & 47.93 & $(5.33)$ \\
\hline セイタカアワダチソウ* & 7.56 & $(5.86)$ & 19.49 & $(4.53)$ & 38.25 & $(5.90)$ \\
\hline ノゲシ & 47.71 & $(5.36)$ & 47.31 & $(21.24)$ & 37.33 & $(6.85)$ \\
\hline ハコヘ & 27.77 & $(6.07)$ & 29.34 & $(9.30)$ & 50.08 & $(9.40)$ \\
\hline ヤブジラミ & 23.17 & $(10.66)$ & 6.93 & $(3.40)$ & 37.65 & $(2.03)$ \\
\hline ヒメガマ & 21.27 & $(1.87)$ & 13.13 & $(2.68)$ & 42.99 & $(2.55)$ \\
\hline オオイヌノフグリ & 19.59 & $(8.59)$ & 22.05 & $(0.07)$ & 42.50 & $(2.51)$ \\
\hline カラスノエンドウ & 22.42 & $(3.67)$ & 32.70 & $(3.67)$ & 49.73 & (16.39) \\
\hline
\end{tabular}

*：既に報告済み

----：3 反復行えず

S.E. $: n=3$

Antifeedant Index $=\% \mathrm{~T} /(\% \mathrm{~T}+\% \mathrm{C}) \times 100$ （\%T：処理区の食害率、\%C：無処理区の食害率 ） 


\section{タイ国産カヤッリグサ属植物由来の昆虫掑食阻害物質}

○森本 正則、藤井優子、駒井 功一郎（近畿大・農）

【目的】前報では、近畿圈にて採集したカヤッリグサ属植物について広食性昆虫 に対する摂食阻害活性物質の検索を実施した。その結果、カヤツリグサ属植物に 特有に含有されるベンゾジフラン類とクマラン関連化合物に昆虫の摂食行動を抑 制する生理活性を認めた。本報では同様の試験を用い、熱帯に植生するカヤッリ グサ属植物について昆虫摂食阻害物質の検索を行ったのでのその結果を報告する。 【材料および方法】カヤツリグサ属植物は夕イ国チェンマイ周辺にて採集し、植 物は乾燥せずに持ち帰った。その後、へキサン抽出を行い減圧濃縮し供試試料と した。これらの試料は所定濃度のアセトン溶液とした後、サッマイモ葉から調整 した直径 $2 \mathrm{~cm}$ リーフディスクに塗布し、溶媒を完全に留去した後、ハスモンヨト ウ（Spodoptera litura F）に対する摂食阻害効果を評価した。対照区は処理区と同 量のアセトンのみを処理した。活性の評価は処理ディスクの掑食率と無処理区の 摂食率を加味した摂食阻害指数を用いた。さらに活性の見られた草種は常法によ り活性化合物の単離、同定を試みた。

【結果】今回供試したカヤツリグサ属植物のヘキサン抽出物のうち、C. stoloniferus, C. pulcherrimus, C. distans, に昆虫摂食阻害活性が確認できた。中でもC. distans は $1.6 \mathrm{mg} / \mathrm{cm}^{2}$ 処理で摂食阻害指数 $9.80 \pm 8.6$ を示し、前報のアオガヤッリ（C. nipponicus）よりも強力な活性成分の存在が示唆された。この抽出物をさらにTLC 分析を行ったところ、ほほ単一のスポットが確認され、これは黄色粉状結晶（融 点 108 度）の化合物として得られた。さらに純化を行い。摂食阻害活性を評価し たところ。 $0.3 \mathrm{mg} / \mathrm{cm}^{2}$ の処理濃度でハスモンヨトウの摂食を完全に阻害した。各 種機器分析によって同様にC. distansより単離、同定されているスカベキノンで あると同定した。本化合物はフラン環部分とジヒドロピラン環部分を有するキノ ン類である事が特徵的である。このブチル側鎖はオゾン分解による生成物の比較 から $R$ 配座であると決定されており（Allan et al）、今回の NMRの H-H 結合定数 值からもこの配座は明らかであった。シペラキノン類の生合成系に関与する化合 物群には様々な類縁体の存在が報告されておりこれらの昆虫生理活性を確認する 必要性がある。また生理活性発現の構造因子を解明することも今後の課題である。

Morimoto, M., Y. Fujii and K. Komai : Insect antifeedant from Cyperaceae in Thailand. 
Table 1. Listing of hexane extracted cyperaceae speices in Thailand and AFI at $1 \mathrm{mg}$ / leafdisk

\begin{tabular}{lcc}
\hline \multicolumn{1}{c}{ Extract } & Plant part & AFI \pm S.E. \\
\hline C. cyperinus & whole plant & $53.26 \pm 8.10$ \\
C. diffusus & whole plant & $34.69 \pm 1.71$ \\
C. distans & leaves and stem & $26.03 \pm 8.88$ \\
& root & $24.40 \pm 10.76$ \\
C. iria & whole plant & $31.58 \pm 9.33$ \\
C. javanicus & whole plant & $28.92 \pm 1.72$ \\
C. nutans & whole plant & $50.92 \pm 4.11$ \\
C. pulcherrimus & whole plant & $41.98 \pm 0.82$ \\
C. stoloniferus & whole plant & $25.15 \pm 5.28$ \\
C. trialatus & whole plant & $47.18 \pm 6.57$ \\
\hline
\end{tabular}

Values shown here are mean \pm SE from 3 experiments.

Table 2. Antifeeding index (AFI) of natural compounds and feeding ratio (FR) of treated leafdisks

\begin{tabular}{lccccc}
\hline compounds & & $1 \mathrm{mg} /$ leaf & $0.25 \mathrm{mg} / \mathrm{leaf}$ & $0.1 /$ leaf & origin \\
\hline scabequinone & AFI & 0 & 2.16 & 4.22 & C. distans \\
& FR & 0 & 6.47 & 1.61 & \\
remirol & AFI & 8.57 & 19.02 & 23.45 & C. nipponicus \\
& FR & 3.84 & 10.31 & 11.33 & \\
cyperaquinone & AFI & 20.98 & 26.03 & 24.00 & C. nipponicus \\
& FR & 9.98 & 13.92 & 16.18 & \\
juglone & AFI & 0 & 0 & 0 & Jugulans \\
& FR & 0 & 0 & 0 & \\
quercetin & AFI & 2.07 & 25.08 & 25.04 & Quercus \\
& FR & 0.66 & 13.07 & 15.96 & \\
\hline
\end{tabular}

Table 3. Spectra data of scabequinone from C. distans

\begin{tabular}{|c|c|}
\hline MS (DI-EI) $70 \mathrm{eV}$ (rel. int. \%) & $260\left(M^{+}\right)(92), 245(40), 217(100)$ \\
\hline${ }^{1} \mathrm{H}-\mathrm{NMR}\left(\mathrm{CDCl}_{3}\right)$ ppm ( $\left.J=\mathrm{Hz}\right)$ & $\begin{array}{l}1.07(6 \mathrm{H} \mathrm{d} . J=6.5) \\
1.55-1.75 \quad(2 \mathrm{H} \mathrm{m} \cdot) \\
2.11(1 \mathrm{H} \mathrm{d} . \mathrm{d} . J=18.0,10.0) \\
2.28(3 \mathrm{H} \mathrm{d} . J=1.0) \\
2.68(1 \mathrm{H} \mathrm{d} . \mathrm{d} . \mathrm{d} . J=18.0,5.0,2.5) \\
3.79(1 \mathrm{H} \text { t. } J=10.0) \\
4.48(1 \mathrm{H} \text { d.t. } J=10.0,2.5) \\
7.46(1 \mathrm{H} \text { d. } J=1.0)\end{array}$ \\
\hline
\end{tabular}

